\title{
Phytoplankton functional traits and seston stable isotopes signature: a functional-based approach in a deep, subalpine lake, Lake Maggiore (N. Italy)
}

\author{
Rossana CARONI, ${ }^{*}$ Gary FREE, ${ }^{1}$ Anna VISCONTI, ${ }^{2}$ and Marina MANCA ${ }^{2}$ \\ European Commission - Joint Research Centre, IES-Rural, Water and Ecosystem Res. Unit, Via E. Fermi 2749, Ispra (VA) I-21027, \\ Italy; ${ }^{1}$ Environmental Protection Agency, McCumiskey House, Richview, Clonskeagh Road, Dublin 14, Ireland; ${ }^{2} \mathrm{CNR}$ Institute of \\ Ecosystem Study, Largo V. Tonolli 50, 28922 Verbania, Italy \\ *Corresponding author: rossana.caroni@jrc.ec.europa.eu
}

\begin{abstract}
The seasonal variation of seston stable isotopes signature of carbon $\left(\delta^{13} \mathrm{C}\right)$ in Lake Maggiore during 2008 was related to seasonal variation of the lake phytoplankton community, investigated in terms of phytoplankton taxonomic groups, morpho-functional groups $(M B F G)$, cell size classes and cell shape classes. Three open water stations were selected to reflect truly pelagic, influenced by littoral and riverine carbon sources; phytoplankton samples were collected from two water depths, 0-20 m and 25-50 m. Among stations differences in $\delta^{13} C$ signatures of seston were statistically non significant, confirming that allochthonous input may become important only after exceptional rainfall events. Nonparametric multiplicative regression (NPMR) was utilized to identify among the phytoplankton parameters (taxonomic groups, MBFG, cell shapes, cell sizes) which were the best predictors of the $\delta^{13} \mathrm{C}$ variation. Bacillariophyceae and two morpho-functional groups, Group 6 (non-flagellated organisms with siliceous exoskeletons) and Group 3 (large filamentous algae with aerotopes) were statistically significant. Non-metric multidimensional scaling (NMS) ordination was used to investigate differences in phytoplankton samples and their relationship with $\delta^{13} \mathrm{C}$ variation. When morphological and functional phytoplankton traits were superimposed, the NMS ordination showed that cylinder cells (for cell shape classes), class 500-2000 um $^{3}$ (for cell size classes) and Group 6 (for $M B F G$ ) were the most related to $\delta^{13} C$ variation. Our study confirms that the variation in the pelagic $\delta^{13} C$ seston most probably reflects changes in phytoplankton carbon isotopic signature, consequent to changes in availability of carbon sources depending on the season and due to different isotopic fractionation of phytoplankton taxonomic groups. Statistical investigations have allowed us to investigate the potential role of phytoplankton morphological and functional traits in the seasonal variation of $\delta^{13} C$ and to suggest their importance in the interpretation of natural stable isotopes studies in lake ecosystems.
\end{abstract}

Key words: stable isotopes, seston, carbon, phytoplankton, functional analysis.

Received: October 2011. Accepted: December 2011.

\section{INTRODUCTION}

The use of natural stable isotopes signatures of carbon $\left(\delta^{13} \mathrm{C}\right)$ has become an important tool to study food web relationships and potential sources of organic matter in aquatic ecosystems. Carbon stable isotope signatures in animals are known to reflect quite closely those of their diet, whereas nitrogen stable isotopes signatures in animals often show considerable enrichment compared to their diet (Peterson, and Fry 1987; Michener, and Schell 1994). These basic principles can provide much information about feeding relationships and carbon sources and have been used extensively in lake food web studies.

Phytoplankton represents the autotrophic, primary producer at the base of the aquatic food web, it is therefore fundamental to identify its isotopic signal when performing a study of the whole-lake food web through stable isotopes.

Several variables can influence phytoplankton $\delta^{13} \mathrm{C}$ in a lake ecosystem. Primary determinants are the isotopic signatures of assimilated inorganic carbon and phytoplankton isotopic fractionation during assimilation. Phy- toplankton $\delta^{13} \mathrm{C}$ can be affected by the taxonomic composition of the phytoplankton communities, because different species fractionate $\delta^{13} \mathrm{C}$ differently (Falkowski 1991, Vuorio et al. 2006).

Seasonal changes in phytoplankton $\delta^{13} \mathrm{C}$ generally occur in lakes (Zohary et al. 1994, Gu, and Schelske 1996, Lehmann et al. 2004). These variations have been related to changes in external loadings, phytoplankton species composition, primary productivity and concentration of dissolved inorganic C and N (DIC and DIN) (Rau et al. 1989, Grey et al. 2001). Differentiated utilization of bicarbonate $\left(\mathrm{HCO}_{3}^{-}\right)$by some phytoplankton species may also contribute to the seasonal $\delta^{13} \mathrm{C}$ variation (Takahashi et al. 1990). Physical variables, such as temperature, are also important determinants of $\delta^{13} \mathrm{C}$ seasonal changes (Rau et al. 1989). Temperature controls the solubility of $\mathrm{CO}_{2}$ and in turn influences the fractionation of carbon isotopes during phytoplankton uptake (Rau et al. 1989, 1992). Water column thermal stratification influences cell activity, nutrients assimilation and competition, light com- 
petition, rate of $\mathrm{CO}_{2}$ and $\mathrm{HCO}_{3}{ }^{-}$diffusion and ultimately phytoplankton species succession, abundance and community structure. Thus water stratification has, in the end, a strong effect on the phytoplankton $\delta^{13} \mathrm{C}$ (Zohary et al. 1994).

While it is established that phytoplankton taxonomic composition can influence phytoplankton $\delta^{13} \mathrm{C}$, less recognized and documented is the potential role of cell size, shape and functional traits for phytoplankton $\delta^{13} \mathrm{C}$ in natural communities. Several models for marine microalgae have demonstrated that species-specific parameters such as $\mathrm{CO}_{2}$ permeability, enzymatic fractionation and cell surface area to volume ratio play a significant role in the variation of plankton $\delta^{13} \mathrm{C}$ (Rau et al. 1996; Popp et al. 1998; Burkhardt 1999). Studies on marine phytoplankton cultures suggested that cell size and cell geometry can significantly influence phytoplankton carbon isotopic fractionation (Goericke et al. 1994; Popp et al. 1998). Phytoplankton cell size is a key feature in the ecological relationships, being related to the efficiency of many ecophysiological processes (nutrient assimilation, photosynthetic efficiency, respiration, buoyancy), most of which are affected by trophic changes (Litchman et al. 2010).

Phytoplankton trait-based approaches are being increasingly used in aquatic ecology (e.g., Reynolds et al. 2002; Salmaso, and Padisak 2007; Litchman, and Klausmeier 2008; Kruk et al. 2010). Classifications based on morphological and functional proprieties generally group species with common features, indicating that algae belonging to a specific group have common morphological characteristics and are powerful predictors of optimum dynamic performance (Reynolds, and Irish 1997). In fact, species-specific morphological characteristics are related to ecological strategies of different phytoplankton species.

Phytoplankton morphological traits are relatively simple to measure and their relation to physiology is potentially well established. Specific growth rates, resource utilization, light competition, grazer resistance all depend on organism dimensions, volume and shape. A tight link between morphology and autecology of species is also suggested by the fact that distribution in time and space is linked to phytoplankton morphometry (Kruk et al. 2010).

The present study examines the temporal variation of the phytoplankton community and seston $(1.2$ to $\leq 76 \mu \mathrm{m})$ $\delta^{13} \mathrm{C}$ in Lake Maggiore during 2008. Previous studies report that $\mathrm{POC}$ and seston in this lake are mainly of autochthonous origin, and that the former is significantly correlated with chlorophyll a $(r=0.651, p<0.001$, d.f. $=134$; Bertoni, and Callieri 1993). This study was part of a wider project investigating aquatic food web relationships in Lake Maggiore through the use of stable isotopes analysis (SIA) of carbon and nitrogen. Part of the research addressed the issue of whether seasonality affected changes in the relative positions of zooplankton taxa in the food web, and in the role of primary and secondary consumers in the transfer of matter and energy along food web pathways (Visconti, and Manca 2011). Because phytoplankton is a key link in lacustrine trophic webs and in specific they represent a source of food for grazing zoo-plankton, we have examined the nature and thus the composition of the phytoplankton community of the lake. Furthermore, along with taxonomic species and group classification, we have explored the potential use of phytoplankton cell size, cell shape and morpho-functional groups for investigating whether they can be related to carbon isotopic variation in the lake.

\section{MATERIALS AND METHODS}

Study site and SIA methods

Lake Maggiore $\left(45^{\circ} 57^{\prime} 30^{\prime \prime} \mathrm{N} ; 8^{\circ} 32^{\prime} \mathrm{E}\right)$ lying at an altitude of 193.30 a.s.l., is the second deepest (mean depth $177 \mathrm{~m}$; maximum $370 \mathrm{~m}$ ) and largest (area $=212.5 \mathrm{~km}^{2}$; volume $37.5 \mathrm{~km}^{3}$ ) subalpine lake in Italy. Phosphorus-limited, the lake was brought back to oligotrophy by the mid eighties (total phosphorus concentration at the winter mixing $c a 10 \mu \mathrm{g} \mathrm{L}^{-1}$ ), after eutrophication in the 1960s and the late 1970 s.

For almost 30 years, a regular monitoring of the lake has been carried out in an open-water station in the deepest part of the lake basin (station Ghiffa, latitude $45^{\circ} 58^{\prime} 30^{\prime \prime} \mathrm{N}$; longitude $8^{\circ} 39^{\prime} 09^{\prime \prime} \mathrm{E}$, depth $370 \mathrm{~m}$ ), with at least monthly frequency. In 2008, two additional sites were sampled near the Toce River inflow (station Baveno: latitude $45^{\circ} 54^{\prime} 28^{\prime \prime} \mathrm{N}$; longitude $8^{\circ} 31^{\prime} 44^{\prime \prime} \mathrm{E}$ ) and in a shallow basin near the lake littoral (station Lesa: latitude $45^{\circ} 49^{\prime} 70^{\prime \prime} \mathrm{N}$; longitude $8^{\circ} 34^{\prime} 70^{\prime \prime} \mathrm{E}$, at the southern end of the lake (Fig. 1).

On each sampling date, 0-20 m (epilimnion) and 25$50 \mathrm{~m}$ (hypolimnion) integrated water samples were collected with a 5 L Niskin bottle, filtered through a $76 \mu \mathrm{m}$ nylon filter. From each, a sub-sample fixed in Lugol acetic solution was taken for phytoplankton abundance and biovolume estimates. Chlorophyll- $a$ was also measured on each date (Lorenzen 1967). In the lab, water samples were filtered through $\mathrm{GF} / \mathrm{C}$ fiber glass filters, to obtain seston material $(1.2-76 \mu \mathrm{m})$.

The water temperature vertical profile and the Secchi depth water transparency were also measured on each date.

The samples were analyzed by continuous flow isotope-ratio mass spectrometry (CF-IRMS) at the G.G. Hatch Stable Isotope Laboratory (University of Ottawa, Canada). The $\delta^{13} \mathrm{C}$ and percentage of carbon was determined. The Elemental analyzer (Vario EL III manufactured by Elementar, Germany) was interfaced with a Conflo II (manufactured by Thermo, Germany), to an Isotope Ratio Mass Spectrometer (IRMS; Delta XP Plus Ad- 
vantage, manufactured by Thermo, Germany). Samples and standards were flash combusted at about $1800^{\circ} \mathrm{C}$ (Dumas combustion) and the resulted gas products carried by helium through columns of oxidizing/reducing chemicals optimized for $\mathrm{CO}_{2}$. The gases were separated by a "purge and trap" adsorption column and sent to IRMS interface, then to IRMS.

Internal standards were $\left(\delta^{13} \mathrm{C}\right.$ in \%o): C-51 Nicotinamide $(0.07,22.95), \mathrm{C}-52 \mathrm{mix}$ of ammonium sulphate + sucrose $(16.58,11.94)$, C-54 caffeine (-16.61, 34.46), blind standard C-55: glutamic acid $(-3.98,28.53)$. Data were reported in Delta notation ( $\delta$ ), the units being per mil (\%o) and defined as $\delta=\left[\left(\mathrm{R}_{\mathrm{x}} \mathrm{R}_{\text {std }}\right) / \mathrm{R}_{\text {std }}\right] \times 1000$ where "R" is the ratio of the abundance of the heavy to the light isotope, " $\mathrm{x}$ " denotes sample and "std" is an abbreviation for standard. All $\delta^{13} \mathrm{C}$ were reported as \%o vs V-PDB (Pee Dee Belemnite) and normalized to internal standards calibrated to international standards IAEA-CH-6 (-10.4\%), NBS-22 (-29.91\%), USGS-40 (-26.24\%o) and USGS-41 $(37.76 \%)$. PDB and V-PDB are identical and interchangeable. Analytical precision based on the laboratory internal standard (C-55, not used for calibration) was better than $0.2 \%$. Standard deviation for $\delta^{13} \mathrm{C}$ was 0.05 .

\section{Laboratory methods for phytoplankton}

The phytoplankton classification and counts were performed on samples fixed by acetic Lugol's solution following the Utermöhl method (Utermöhl 1958; Lund et al. 1958; Rott 1981). The phytoplankton analysis was done under an inverted microscope; small species were enumerated under $400 \times$ magnification while bigger and colonial species under a lower $200 \times$ magnification. Cell biovolumes were calculated from recorded abundance and specific biovolumes approximated to simple geometrical solids (Rott 1981). Taxa have been classified according to phytoplankton keys edited by A. Pasher- Sußwasserflora von Mitteleuropa and by G. Huber-Pestalozzi-Das Phytoplankton des Süßwassers.

In this study the functional classification of phytoplankton species was carried out according to Kruk et al. (2010); the so-called "morphologically based functional classification" abbreviated to MBFC or morphologically based functional group (MBFG), listed in Fig. 4. Phytoplankton was classified in five size classes (minimum visible-100 $\mu^{3}, 100-500 \mu \mathrm{m}^{3}, 500-2000 \mu \mathrm{m}^{3}, 2000-5000$ $\mu \mathrm{m}^{3}$ and $>5000 \mu \mathrm{m}^{3}$ ) according to species biovolume. Phytoplankton cell shape classification was carried out according to Hillebrand et al. (1999), listed in Fig. 4.

\section{Statistical methods}

Non-parametric multiplicative regression (NPMR) was used to model $\delta^{13} \mathrm{C}$ using taxonomic groups, cell size, cell shape and morpho-functional groups. NPMR was ap-

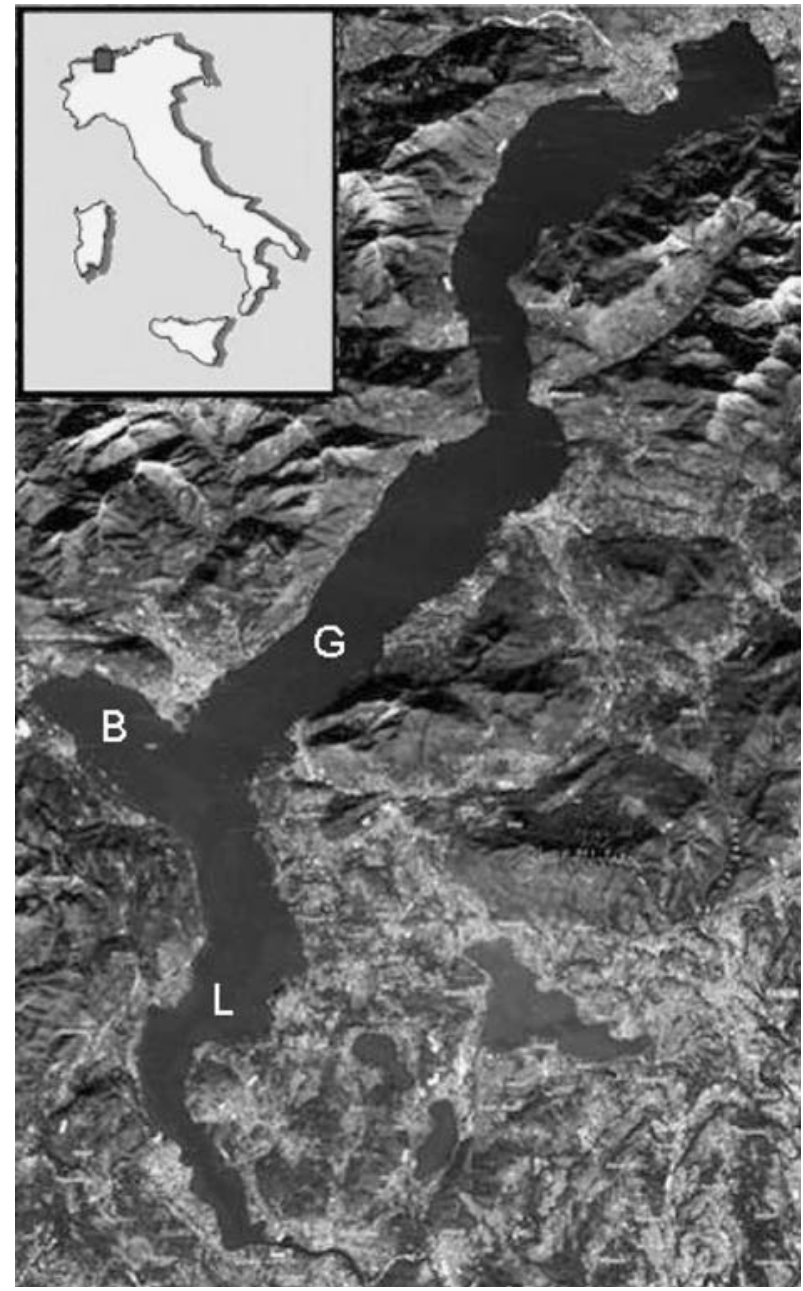

Fig. 1. Sampling stations from which phytoplankton samples were collected in Lake Maggiore in $2008(\mathrm{G}=\mathrm{Ghiffa}, \mathrm{B}=$ Baveno, $\mathrm{L}=$ Lesa).

plied using the software HyperNiche version 1.46 (McCune, and Mefford 2004). Non-metric multidimensional scaling (NMS) ordination was used to investigate differences among phytoplankton samples. NMS was applied using the software PC-ORD (McCune, and Mefford 2006).

\section{RESULTS}

Differences in seston $\delta^{13} \mathrm{C}$ among the three monitored stations (Ghiffa, Baveno, Lesa) were not statistically significant (nonparametric Kruskal-Wallis test, $\mathrm{n}=35$; $P=0.075$ ). Density and biovolume of phytoplankton in the three monitored stations were similar (Fig. 2), with density ranging between 550 and 9000 cells $\mathrm{mL}^{-1}$, excluding the maximum value at Ghiffa in July with 21,900 cells $\mathrm{mL}^{-1}$. Biovolume ranged between 77 (in autumn) and 1480 (in spring) $\mathrm{mm}^{3} \mathrm{~m}^{-3}$.

Differences of seston $\delta^{13} \mathrm{C}$ in the two layers (depth of 
0-20 $\mathrm{m}$ and depth of 25-50 m), in all three stations pooled together, were borderline significant (Wilcoxon test; $P=0.059 ; \mathrm{n}=24)$. The difference of phytoplankton total biovolume in the two layers (Fig. 2), in all three stations pooled together, was significant $(P=0.0022 ; \mathrm{n}=24)$. Phytoplankton biovolume differences were confirmed by chlorophyll a data, with results statistically different in the two depth layers (Wilcoxon test; $P=0.008$; $\mathrm{n}=18$ ).

The seston $\delta^{13} \mathrm{C}$ followed a seasonal trend (Fig. 3) with depleted values in winter and springtime and enriched values during the summer. Seasonal changes in $\delta^{13} \mathrm{C}$ (pooled data from the epilimnion and hypolimnion) were statistically significant $(\mathrm{n}=23 ; F=5.67 ; P=0.006)$, with higher (less negative) $\delta^{13} \mathrm{C}$ signatures in summer $(-28.13$; $P=0.01)$ than in spring $(-31.21 ; P=0.012)$ and winter (30.74; $\mathrm{P}=0.038$ ) (Scheffè post-hoc test).

The phytoplankton assemblage's structure changed seasonally (Fig. 2). In general, the phytoplankton community of the lake was dominated by Bacillariophyceae during late winter and spring, especially with large pennate species like Asterionella formosa, Fragilaria crotonensis and Tabellaria flocculosa, along with smaller species like Cyclotella sp. During the summer months there was coexistence of Bacillariophyceae and Cyanobacteria, the latter group mainly represented by colonial species like Aphanotheche clathrata, Snowella lacustris and filamentous species like Planktothrix agardii/rubescens and Geitlerinema sp.

During the summer also the Crysophyceae were an important group with species like Uroglena sp. and Chrisochromulina parva. In the autumn the assemblage was dominated once again by Bacillariophyceae, mostly with Asterionella formosa and Cyclotella species. A complete taxonomic list and a detailed description are given in Manca et al. (2009).

In terms of density and biovolume there was, above all in the summer, a decrease of Bacillariophyceae and an increase of Cyanobacteria (Fig. 2). This was particularly evident in the epilimnion $(0-20 \mathrm{~m})$, and at the Ghiffa station where a small bloom of the cyanobacteria species Aphanotheche clathrata occurred in July.

The phytoplankton community was analyzed according to different parameters (as described in the Methods), namely cell shapes, cell sizes (biovolume classes) and
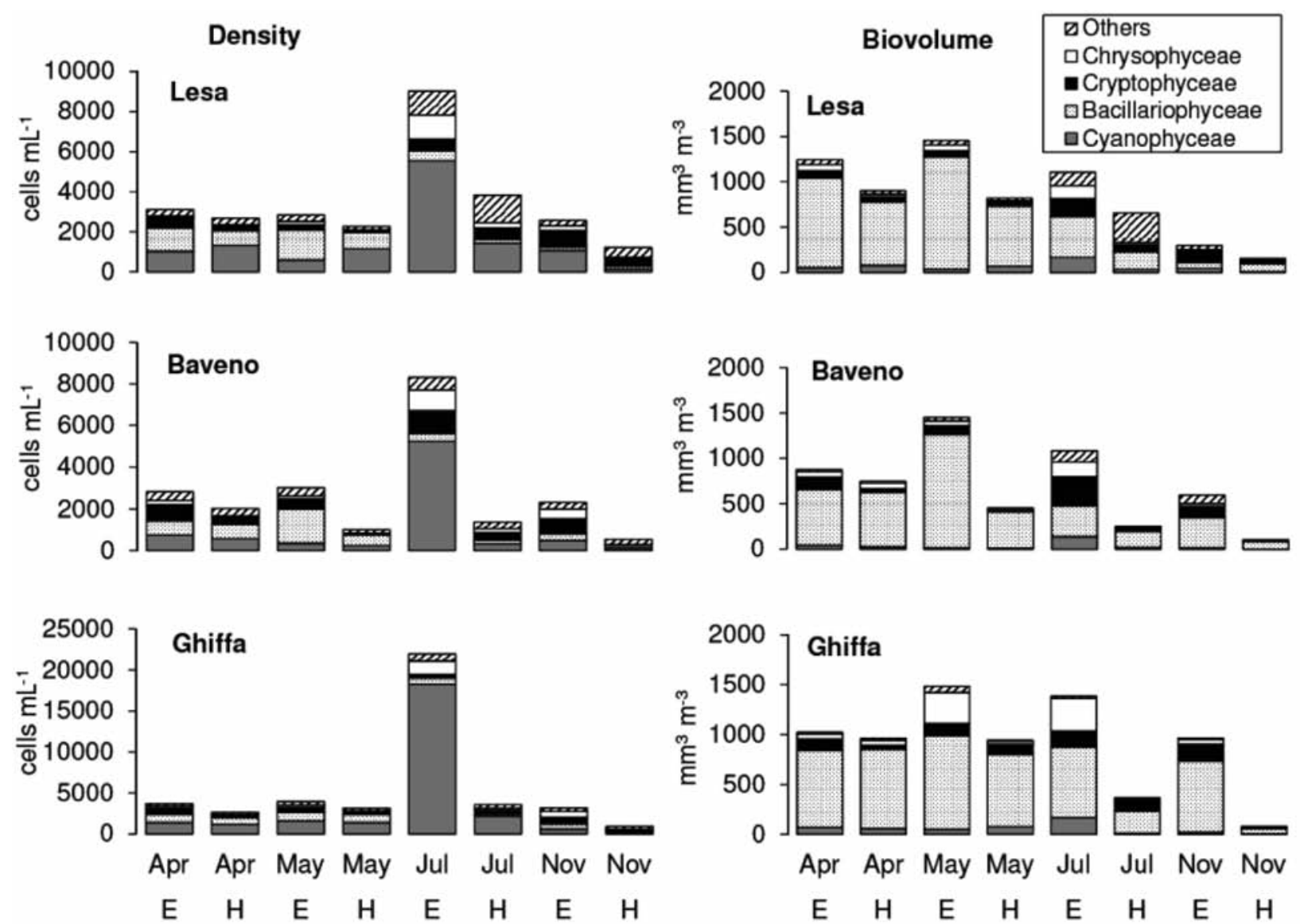

Fig. 2. Seasonal trend of phytoplankton $\delta^{13} \mathrm{C}$ in the three stations (GHI: Ghiffa, BAV: Baveno, LES: Lesa). Data from the two layers were pooled. 
morpho-functional or MBFG groups (Fig. 4).

According to cell shapes, the community was quite diversified in springtime; during the summer there was a relative increase in density and biovolume of phytoplankton species with prolate spheroid shape particularly in the epilimnion (0-20 m) and quite evident at the Ghiffa station, together with a general decrease of cylinder and box shaped cells in all the three stations.

According to sizes, the community was quite diversified in terms of biovolume with the $500-2000 \mu^{3}$ generally as the main size class (Fig. 4). In contrast, the dominant class in term of density in both epilimnion and hypolimnion (0-20 $\mathrm{m}$ and $25-50 \mathrm{~m})$ was the smallest 0.1 $100 \mathrm{um}^{3}$, during the whole period and in all the three stations. In the summer there was a marked increase of such size class $\left(0.1-100 \mu \mathrm{m}^{3}\right)$ of small organisms, particularly in the epilimnion (data not shown).

According to morpho-functional groups the phytoplankton community, in terms of biovolume, in both layers was generally dominated by Group 6 (non-flagellated organisms with siliceous exoskeletons). In the summer the relative importance of this group to some extent decreased
(Fig. 4). In contrast, in terms of density, the most important MBFG groups were Group 6, Group 3 (large filamentous algae with aerotopes) and Group 1 (small organisms with high surface/volume ratio). However, in the summer Group 7 (large mucilaginous colonies) was the most numerous morpho-functional group in both layers $(0-20 \mathrm{~m}$

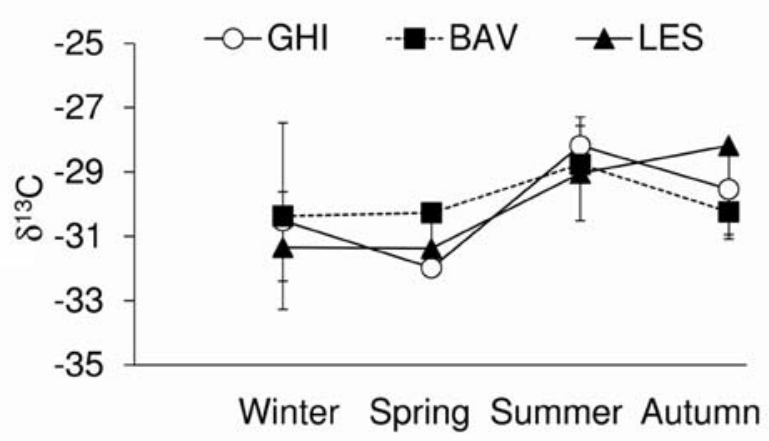

Fig. 3. Seasonal trend of phytoplankton $\delta^{13} \mathrm{C}$ in the three stations (GHI: Ghiffa, BAV: Baveno, LES: Lesa). Data from the two layers were pooled.

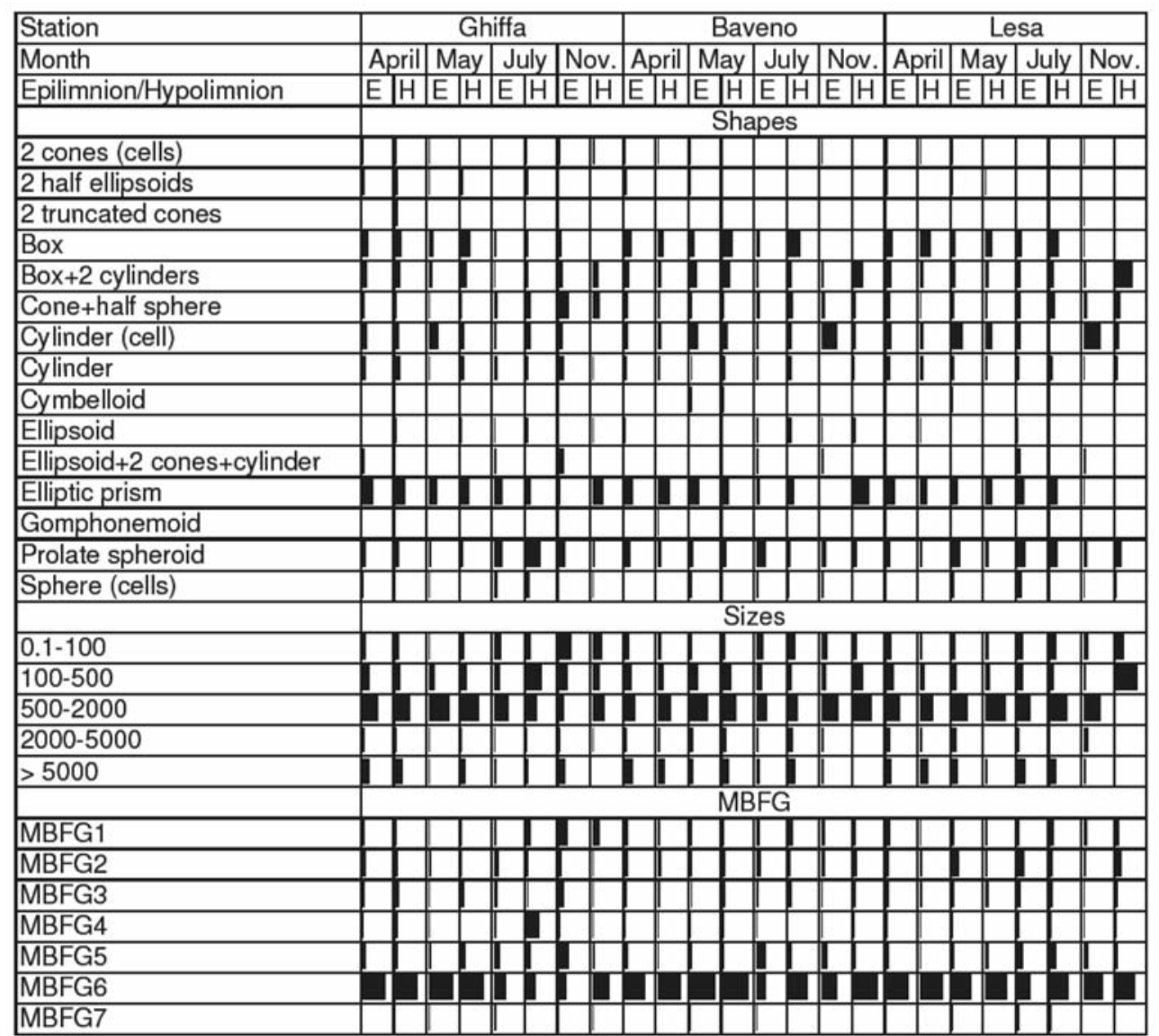

Fig. 4. Seasonal trends of the phytoplankton for Shapes, Sizes and MBFG groups for the three sites (Ghiffa, Baveno and Lesa). Each bar in the matrix represents percentage biovolume in the sample and was calculated separately for Shapes, Sizes and MBFG. 
and $25-50 \mathrm{~m}$ ) in all the three stations, but particularly at Ghiffa; a correspondent decrease in the relative importance of Group 6 occurred. NPMR was utilized to search all possible phytoplankton descriptors to determine the best predictors of $\delta^{13} \mathrm{C}$ variation. Through an iterative process NPMR searches all possible multiplicative combinations of variables to produce a model using the best predictors. Four statistically significant models were found $(P \leq 0.05)$ through NPMR (Tab. 1). For the different taxonomic groups, Bacillariophyceae (BACILL) had the most important relation with $\delta^{13} \mathrm{C}$. For MBFG groups, Group 6 (non-flagellated organisms with siliceous exoskeletons) and Group 3 (large filamentous algae with aerotopes) seemed to be the most related to $\delta^{13} \mathrm{C}$.

Analyzing the data through multiple linear regression models between phytoplankton parameters (taxa groups, MBFG, shapes, sizes) and $\delta^{13} \mathrm{C}$ also revealed significant $(p<0.02)$ relationships (Tab. 2). There were similarities to the NPMR results with Bacillariophyceae and MBFG
6 being significant predictors of $\delta^{13} \mathrm{C}$. NMS analysis carried out using taxonomic composition revealed that samples were mainly separated according to depth (axis 1), with most of the epilimnetic samples (0-20 m) found on the left of the ordination and the hypolimnetic samples (25-50 m) on the right (Fig. 5). Shape, size and morphofunctional classification classes were then superimposed as secondary variables in joint plots, together with $\delta^{13} \mathrm{C}$ values, in order to observe patterns as indicated by the direction and length of overlain lines (Figs 5A, 5B and 5C).

In the NMS ordination of phytoplankton with cell shapes, the $\delta^{13} \mathrm{C}$ gradient stretched from the center of the plot towards the bottom (Fig. 5A). Cylinder shapes (a category which mainly included the diatom Cyclotella sp.) were positioned at the top of the plot, directly opposite to $\delta^{13} \mathrm{C}$, probably indicating the light-est (more negative) $\delta^{13} \mathrm{C}$ signal among the cell shapes classes. Cyclotella $\mathrm{sp}$. density and biovolume in all the three lake stations decreased considerably during the summer, a pattern that

Tab. 1. NPMR results for prediction of phytoplankton $\delta^{13} \mathrm{C}$. Data were expressed as eight types.

\begin{tabular}{|c|c|c|c|c|c|c|c|c|c|c|}
\hline Data type & $\begin{array}{l}\text { Density or } \\
\text { biovolume }\end{array}$ & Eval xR ${ }^{2}$ & $P$ & $\begin{array}{c}\text { Average size } \\
\text { neighbourhood }\end{array}$ & Variable 1 & Tolerance & Variable 2 & Tolerance & Variable 3 & Tolerance \\
\hline MBFG & density & 0.164 & 0.02 & 11.9 & MBFG3 & 534 & & & & \\
\hline MBFG & biovolume & 0.131 & 0.03 & 12.8 & MBFG6 & 359718 & & & & \\
\hline Taxa Groups & density & 0.129 & 0.02 & 13.5 & BACILL & 453 & & & & \\
\hline Taxa Groups & biovolume & 0.131 & 0.04 & 12.8 & BACILL & 359718 & & & & \\
\hline Shapes & density & 0.207 & 0.18 & 12.2 & 2 half e & 1.3 & box +2 & 162 & cylinder & 658 \\
\hline Shapes & biovolume & 0.135 & 0.21 & 13.1 & box & 219332 & box +2 & 66874 & & \\
\hline Size & density & 0.005 & 0.29 & 14.8 & $500-2000$ & 322 & & & & \\
\hline Size & biovolume & 0.007 & 0.41 & 13.4 & $0.1-100$ & 175688 & $500-2000$ & 360906 & & \\
\hline
\end{tabular}
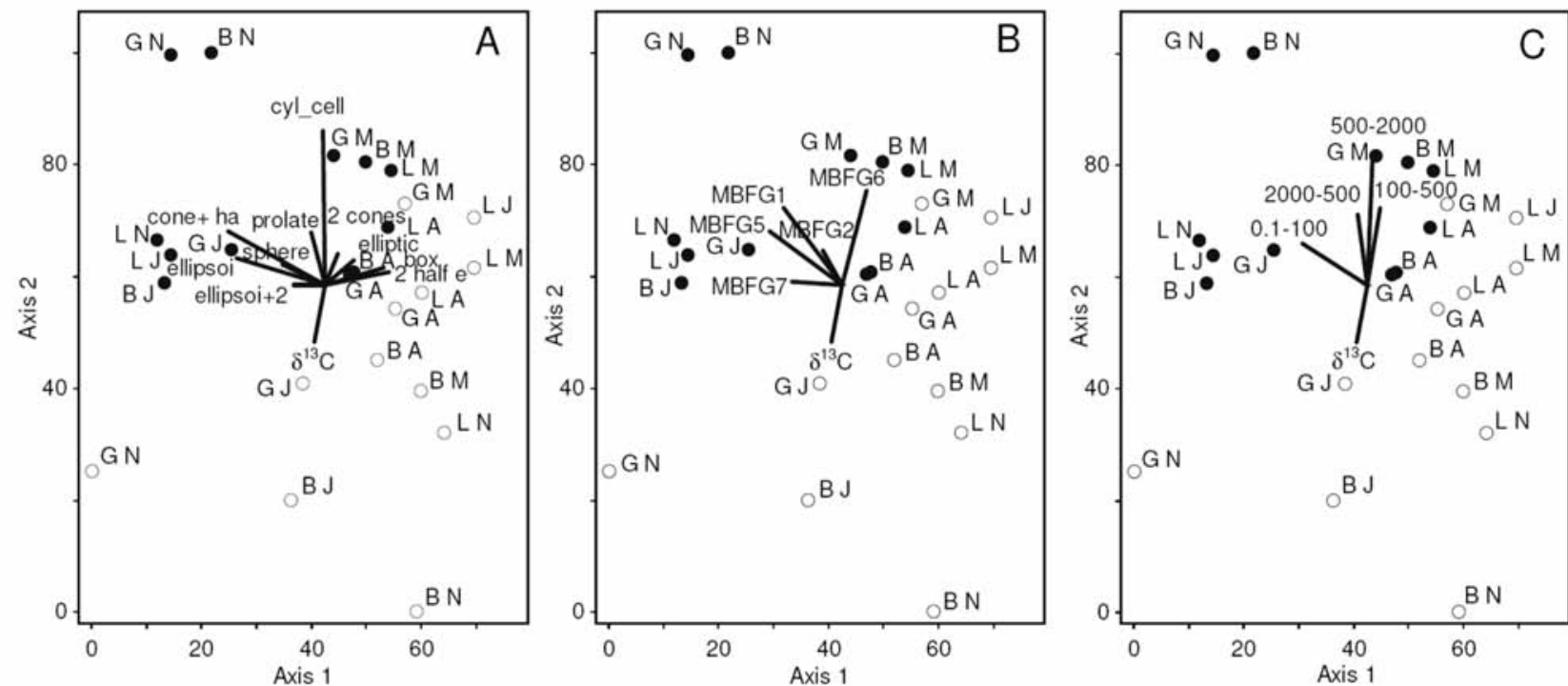

Fig. 5. NMS ordination of phytoplankton (square root transformed quantitative data). Parameters that had a correlation with an axis $\geq 0.1$ were overlain for cell shapes (A), MBFG (B), Sizes (C), and $\delta^{13} \mathrm{C}$. Stress=8.80936. Samples are coded by station initial (G: Ghiffa, B: Baveno and L: Lesa) and month initial (A: April, M: May, J: July, N: November). Depth is indicated by closed circles (epilimnion) and open circles (hypolimnion). 
further supports the hypothesis of their light $\delta^{13} \mathrm{C}$ fractionation. Also prolate shape cells were positioned in the upper part of the plot, although with a less extreme position than cylinder shapes. Cell shapes indicated with box (a shape category which included the diatom Tabellaria sp.) were located in the right part of the plot, where deep samples were usually found, and slightly opposite to increasing $\delta^{13} \mathrm{C}$.

When cell sizes were overlain (Fig. 5C) the class of 500-2000 $\mu^{3}$ appeared in the upper part of the ordination, likely representing the lightest $\delta^{13} \mathrm{C}$ signal size class. The class with the smallest cells, or size class 0.1-100 $\mu \mathrm{m}^{3}$, was positioned in the upper part of the plot indicating a relatively light $\delta^{13} \mathrm{C}$ signal, and toward the left of the plot which was dominated by epilimnion samples.

In the ordination with the MBFG groups, Group 6 (mainly Bacillariophyceae) was positioned in the upper part of the plot, likely representing the lightest $\delta^{13} \mathrm{C}$ signal of the function-morphological groups (Fig. 5B). Also Group 1 (small organisms with high S/V ratio) was located in the upper part of the ordination and toward the left, or towards epilimnion samples. Group 7 (large mucilaginous colonies) appeared in the left part of the plot, being more related with axes 1 and thus found mainly in epilimnion samples; its vector appeared the closest to $\delta^{13} \mathrm{C}$, potentially indicating a MBFG group with enriched $\delta^{13} \mathrm{C}$.

\section{DISCUSSION}

The use of $\delta^{13} \mathrm{C}$ POM in ecological and environmental studies in lakes is based on an assumption that POM is a surrogate of phytoplankton. However, this assumption is not always valid because POM samples also include nonliving matter derived from in situ production, external inputs and from flagellates and ciliates. To date a major problem in studies of plankton isotopes has been the separation of phytoplankton from other microbes and detritus (Jones et al. 1998), an operation that might be very difficult or impossible to finally obtain pure phytoplankton materials without contamination from other coexistent particulates (Gu et al. 2011). As indicated by Gu et al. (2011), several reasons warrant/justify the continued use of stable isotopes of POM in research on biogeochemical processes in lakes. First, biological activities likely dictate the responses of POM to environmental changes although POM is not exclusively composed of phytoplankton. Second, microbial organisms and grazers that obtain nutrients or energy from phytoplankton may share similar isotope compositions with their sources because isotopic fractionation between consumers and their prey is typically small and predictable (Post 2002). Detritus derived from phytoplankton may also resemble, if it is not identical, to its source.

Furthermore, for Lake Maggiore, a highly significant
Tab. 2. Multiple linear regression results for relationship between $\delta^{13} \mathrm{C}$ and phytoplankton parameters (biovolume).

\begin{tabular}{llcc}
\hline Data type & Variables & $\mathrm{R}^{2}$ & $P$ \\
\hline MBFG & MBFG 6, MBFG 4 & 43.6 & $<0.02$ \\
Taxa groups & BACILL & 24.8 & 0.01 \\
Shapes & Cylinder (cells), sphere & 42.1 & $<0.001$ \\
\hline
\end{tabular}

correlation between chlorophyll- $a$ and sestonic carbon concentration was found over the long term (Bertoni, and Callieri 1993), suggesting that POM in the lake is mainly of autoctonous origin and likely made up of algal cells and that $\delta^{13} \mathrm{C}$ signatures of seston in this lake are mainly related to phytoplankton. As in other deep lakes such as Lake Geneva, phytoplankton largely contributes to seston in Lake Maggiore epilimnion (Morabito et al. 2009).

In this study, overall differences among the three stations in sestonic $\delta^{13} \mathrm{C}$ signature were statistically non-significant, suggesting that the impact of allochthonous material from the River Toce, which was expected in one of the stations (station Baveno; de Bernardi et al. 1988) may only exceptionally become important (i.e., after heavy rainfall events). Phytoplankton density and biomass values were also similar in the three monitored stations. The among-stations close similarity of carbon isotopic signatures may reflect a substantial homogeneity in phytoplankton abundance and community composition. Although a recent study (Morabito et al. 2009) found a gradient in the horizontal distribution of summer phytoplankton in the lake from north to south, such variability was not evident in our study likely due to differences in the position and number of the stations monitored.

A vertical gradient of phytoplankton density and biomass, in the three stations, was observed with generally higher values in the epilimnion than in the hypolimnion, particularly manifest in the summer during thermal stratification. This gradient was confirmed by the difference in chlorophyll a concentrations in the two layers.

In this study the pelagic seston $\delta^{13} \mathrm{C}$ followed a seasonal trend (Fig. 3) with depleted values in winter and springtime, less negative values during the summer and again more depleted values in the autumn. These $\delta^{13} \mathrm{C}$ variations corresponded to the water temperature seasonal trend in the Lake Maggiore during 2008 (Manca et al. 2009; Visconti, and Manca 2011). Similar $\delta^{13} \mathrm{C}$ seasonal trends have been observed in other deep lakes, such as Lake Geneva (Perga, and Gerdeaux 2006). Also in smaller lakes such as Lake Wauberg (Gu et al. 2006), enriched phytoplankton $\delta^{13} \mathrm{C}$ values typically occurred in warm months and were generally accompanied by high water temperature, high $\mathrm{pH}$ and low DIC concentration.

The variation in the pelagic $\delta^{13} \mathrm{C}$ seston baseline most probably reflects changes in phytoplankton carbon isotopic signature (Zohary et al. 1994), consequent to 
changes in availability of carbon sources depending on the season, and the degree of fractionation during the uptake of dissolved inorganic carbon (DIC) for the photosynthetic activity. Plankton collected during periods of high biomass and primary productivity tends to exhibit $\delta^{13} \mathrm{C}$ enrichment (Degens et al. 1968; Fry, and Wainright 1991; Zohary et al. 1994; France et al. 1997) and heaviest (i.e., less negative) $\delta^{13} \mathrm{C}$ signatures, due to reduced isotopic fractionation at high cell densities or growth rates, or a switch to utilizing $\mathrm{HCO}_{3}{ }^{-}$as $\mathrm{CO}_{2}$ concentration is depleted at high cell densities or growth rates (France et al. 1997; Leggett et al. 1999, 2000). Lighter (i.e., more negative) $\delta^{13} \mathrm{C}$ signatures are again typically observed in the autumn with the gradual thermal destratification and increasing contribution of dissolved carbon from the hypolimnion, leading to a seasonal minimum during winter mixing (Zohary et al. 1994).

In this study, the phytoplankton community underwent some structural and taxonomic changes during the year. Diatoms represented the main group in the winter and springtime (when $\delta^{13} \mathrm{C}$ was more negative), and they decreased both in density and biovolume in the summer (when $\delta^{13} \mathrm{C}$ was less negative). This observed trend is typical of Lake Maggiore in recent years and has been confirmed for 2008 by a specific monitoring of phytoplankton for the whole year (Morabito et al. 2009). Diverse studies on phytoplankton carbon fractionation (e.g., Hollander, and McKenzie 1991; Zohary et al. 1994; Jones et al. 1998) found that diatoms have lighter isotopic compositions than other algal groups. For instance, values of 32\%o of $\delta^{13} \mathrm{C}$ for Melosira granulata in winter in Lake Kinnereth and values of 31.2\%o for large diatoms in Loch Ness were observed.

While $\delta^{13} \mathrm{C}$ depletion in diatoms, compared to small phytoplankton, in lakes has been reported [e.g., Lake Kinnereth by Zohary et al. (1994), Lake Greifen by Hollander, and McKenzie (1991) and Loch Ness by Jones et al. (1998)], several studies reported that marine diatoms have more positive $\delta^{13} \mathrm{C}$ signatures than that of small phytoplankton (Gearing et al. 1984; Fry, and Wainright 1991, $\mathrm{Gu}$, and Schelske 1996). One possible explanation for the $\delta^{13} \mathrm{C}$ depletion in lacustrine diatoms is the lipid stored within the cells which is a ${ }^{13} \mathrm{C}$-poor bio-chemical compound (Parker 1964; Gu, and Schelske 1996).

In this study, Cyanobacteria, both in density and biovolume, increased in the lake in the summer (when $\delta^{13} \mathrm{C}$ was less negative), particularly in the epilimnion. Cyanobacteria are expected to have a high $\delta^{13} \mathrm{C}$ due to their use of $\mathrm{HCO}_{3}{ }^{-}$and their efficient utilization of $\mathrm{CO}_{2}$ generated in the carboxysome (Goericke et al. 1994). During the summer months, with thermal stratification conditions, $\mathrm{pH}$ typically increases in the epilimnion due to the high rate of $\mathrm{CO}_{2}$ uptake for increasing primary production and algal blooms. In these conditions the carbon balance might switch from $\mathrm{CO}_{2}$ to $\mathrm{HCO}_{3}$ - dominance, and groups like Cyanobacteria, capable of using $\mathrm{HCO}_{3}^{-}$, may have competition advantages and dominate the phytoplankton community. Because $\delta^{13} \mathrm{C}$ of $\mathrm{HCO}_{3}{ }^{-}$is on average $8 \%$ higher than that of $\mathrm{CO}_{2}$ (Mook et al. 1974), phytoplankton are enriched with $\delta^{13} \mathrm{C}$ when using $\mathrm{HCO}_{3}$ as their carbon source (Gu et al. 2006).

Detailed analysis of the phytoplankton community in this study revealed that the increase of Cyanobacteria in the summer at the surface of Ghiffa Station (the pelagic station, maximum depth) was mainly due to the colonial Aphanotheche clathrata. Our findings are in agreement with the ecophysiology of this species and with other studies of deep subalpine lakes (Salmaso 2000; Morabito 2002), where this species may occur at significant abundance in the summer. According to Kruk et al. (2010) Aphanotheche clathrata belongs to the morpho-functional Group 7 (components with low surface/volume ratio), which was also the predominant group in our study during the summer. Such relatively low ratio of phytoplankton surface/volume might be related to the general enrichment of $\delta^{13} \mathrm{C}$ observed in the lake during the summer, being in agreement with the finding of Popp et al. (1998) on cell shape and surface/volume ratio. This was particularly evident in the Ghiffa Station, where colonies of A. clathrata formed a little bloom and where we found the more enriched values of $\delta^{13} \mathrm{C}$ ( $27 \%$ ) of the three lake stations.

In our statistical analysis by NPMR, we have investigated which, among all phytoplankton parameters, could be the best predictors of phytoplankton $\delta^{13} \mathrm{C}$ variations (Tab. 1). Among the taxonomic groups, Bacillariophyceae was the most important in relation with $\delta^{13} \mathrm{C}$ trend. For the MBFG groups, Group 3 (large filamentous algae with aerotopes) and Group 6 (non-flagellated organisms with siliceous exoskeletons) seemed to be the most related to $\delta^{13} \mathrm{C}$ trend. As described earlier, Bacillariophyceae (included in MBFG 6) was the dominant taxonomic group in late winter and spring and its importance decreased during the summer, when Cyanobacteria (included in MBFG 3 ) were increasing. These two taxonomical groups usually represent the dominant groups in the phytoplankton community of Lake Maggiore (Morabito et al. 2009).

Some multiple linear regression models run with phytoplankton data and $\delta^{13} \mathrm{C}$ variation were significant. In particular, the taxonomic group of Bacillariophyceae was related to $\delta^{13} \mathrm{C}$ variation, so were cylinder shaped cells and MBFG 6, both categories including mainly Bacillariophyceae. The pattern of $\delta^{13} \mathrm{C}$ seasonal variations showed that at less negative values of $\delta^{13} \mathrm{C}$ found during the summer, the phytoplankton predictors found above have decreased, thus indicating to potentially represent phytoplankton groups with light $\delta^{13} \mathrm{C}$.

More interconnections among the parameters were revealed by the NMS analysis, which primarily showed that 
the depth factor was a strong determinant in the ordinations. The $\delta^{13} \mathrm{C}$ gradient seemed to be mainly related to size class $500-2000 \mu \mathrm{m}^{3}$ (the most important in the lake in terms of biovolume and including most of the diatom species), cylindrical shaped cells (including all Cyclotella species and in agreement with the multiple linear regression model), and with the morpho-functional groups MBFG 6 (indicating a light $\delta^{13} \mathrm{C}$ ) and MBFG 7 (indicating enriched $\left.\delta^{13} \mathrm{C}\right)$.

\section{CONCLUSIONS}

Statistical investigation of the phytoplankton parameters that might be predictors of $\delta^{13} \mathrm{C}$ variation in this study seems to be mainly related to the Bacillariophyceae taxonomic group and to MBFG 6 (non-flagellated organisms with siliceous exoskeletons). More interconnection among the parameters considered emerged from the NMS analysis.

Phytoplankton shape doesn't seem to be per se a good indicator of $\delta^{13} \mathrm{C}$ variation. For instance, prolate cells, which were postulated to be a good predictor from direct observations, included diverse taxonomic groups which, from the literature have also different $\delta^{13} \mathrm{C}$ fractionation. It included, in fact, Cyanobacteria which are supposed to have enriched $\delta^{13} \mathrm{C}$ fractionation, and mainly all the Chrysophyta taxa which are supposed, instead, to have depleted $\delta^{13} \mathrm{C}$ fractionation. The sum of the two groups probably reduced the differences visible thereby reducing significance in the statistical tests we have applied. The same comment is valid for the group of cylinder colonies, which included both filamentous Cyanobacteria (enriched $\delta^{13} \mathrm{C}$ fractionation) and filamentous Bacillariophyceae (depleted $\delta^{13} \mathrm{C}$ fractionation). However, a better indicator shape group might be the cylinder shaped cells (including mainly Cyclotella sp.) since they resulted to have a significant relationship with $\delta^{13} \mathrm{C}$ in the multiple linear regression and in the NMS analysis.

Phytoplankton size classes were not found to be statistically significant with $\delta^{13} \mathrm{C}$ variation, both through the NPMR model and the multiple linear regression model. However, NMS analysis revealed that size class 500-2000 $\mu \mathrm{m}^{3}$ was the best related to $\delta^{13} \mathrm{C}$ variations. Although the classification of a phytoplankton assemblage in terms of size spectra could represent a valid instrument in describing the response to environmental gradients (Kamenir, and Morabito 2009) and in developing phytoplankton trophic indices (Phillips et al. 2011), its use in lake isotopic studies needs further insight and studies to be considered. In particular, future and already existent laboratory studies should be coupled with more investigations of carbon isotopes in natural environments.

In this study, the best predictor of $\delta^{13} \mathrm{C}$ variations seemed to be the phytoplankton taxonomic groups and the morpho-functional groups (MBFG). In particular, Bacyl- lariophyceae and MBFG 6 were significantly related to $\delta^{13} \mathrm{C}$ variations in both NPMR model and in the multiple linear regression model and also the NMS analysis revealed their potential importance as predictor of $\delta^{13} \mathrm{C}$ variations. The importance of morphological and functional traits in shaping phytoplankton assemblages is well recognized and increasingly used in ecology (see the review by Litchman et al. 2010). Already thirty years ago Margalef (1978) and Reynolds (1984) suggested that morphology and functions of phytoplankton cells are determinant for the role of the organisms in the environment and that a trait-based approach can explain species distribution and auto-ecology. A simple and mechanistic classification of phytoplankton results to be strongly connected with the functioning of the community.

Our study suggests that morpho-functional grouping of phytoplankton could be a good predictor for $\delta^{13} \mathrm{C}$ variations in lakes, contributing to a better understanding of the factors influencing $\delta^{13} \mathrm{C}$ signature and variation in aquatic ecosystems. This might represent a supporting and parallel result also in the utilization of phytoplankton functional traits classification in current research for developing models and indices of water ecological quality (Phillips et al. 2011).

Our study confirms that the variation in the pelagic $\delta^{13} \mathrm{C}$ seston most probably reflects changes in phytoplankton carbon isotopic signature, consequent to changes in availability of carbon sources depending on the season and due to different isotopic fractionation of phytoplankton taxonomic and morpho-functional groups. Overall, this study shows the value of detailed information on phytoplankton composition and morpho-functional traits when interpreting isotopic signatures and pathways of organic matter in lake food webs.

\section{ACKNOWLEDGMENTS}

This study was funded to M. Manca by the Commissione Internazionale per la Protezione delle Acque ItaloSvizzere (CIPAIS), Project on: "Studies on zooplankton and the pelagic food web by means of carbon and nitrogen Stable Isotope Analysis" and by the "Emilia Stella scholarship" to Anna Visconti. We wish to thank two anonymous reviewers for critical comments and a peer revision of the manuscript.

\section{REFERENCES}

Bertoni R, and Callieri C. 1993. Organic carbon trend during the oligotrophication of Lago Maggiore. Mem. Ist. ital. Idrobiol. 52: 191-205.

Burkhardt S, Riebesell U, and Zondervan I. 1999. Effects of growth rate, $\mathrm{CO}_{2}$ concentration, and cell size on the stable carbon isotope fractionation in marine phytoplankton. Geochim. Cosmochim. Acta 63: 3729-3741.

de Bernardi R, Giussani G, and Manca M. 1988. Seasonal evo- 
lution of Cladocera in Lago Maggiore (N. Italy) as influenced by environmental parameters. Verh. Internat. Verein. Limnol. 23: 530-534.

Degens ET, Guillard R, Sackett WM, and Hellebust JA. 1968. Metabolic fractionation of carbon isotopes in marine plankton. Temperature and respiration experiments. Deep Sea Res. 15: 1-9.

Falkowski PG. 1991. Species variability in the fractionation of $13 \mathrm{C}$ and $12 \mathrm{C}$ by marine phytoplankton. J. Plankton Res. 13: 21-28.

France RL, Del Giorgio PA, and Westcott KA. 1997. Productivity and heterotrophy infuences on zooplankton ${ }^{13} \mathrm{C}$ in northern temperate lakes. Aquat. Microb. Ecol. 12: 85-93.

Fry B, and Wainright SC. 1991. Diatom sources of ${ }^{13} \mathrm{C}-$-rich carbon in marine food webs. Mar. Ecol. Prog. Ser. 76: 149-157.

Gearing JN, Gearing PJ, Rudnick DT, Requejo AG, and Hutchins MJ. 1984. Isotopic variability of organic carbon in a phytoplankton-based, temperate estuary. Geochim. Cosmochim. Acta 48: 1089-1098.

Goericke R, Montoya JP, and Fry B. 1994. Physiology of isotopic fractionation in algae and cyanobacteria. In: K. Lajhta, and R.H. Michener (Eds), Stable isotopes in ecology and environmental science. Blackwell Scientific Publications, Cambridge, MA: 187-221.

Grey J, Jones RI, and Sleep D. 2001. Seasonal changes in the importance of the source of organic matter to the diet of zooplankton in Loch Ness, as indicated by stable isotope analysis. Limnol. Oceanogr. 46: 505-513.

Gu B, Chapman AD, and Schelske CL. 2006. Factors controlling seasonal variations in stable isotope composition of particulate organic matter in a soft water eutrophic lake. Limnol. Oceanogr. 51: 2837-2848.

Gu B, and Schelske CL. 1996. Temporal and spatial variations in phytoplankton carbon isotopes in a polymictic subtropical lake. J. Plankton Res. 18: 2081-2092.

Gu B, Schelske CL, and Waters MN. 2011. Patterns and controls of seasonal variability of carbon stable isotopes of particulate organic matter in lakes. Oecologia 165: 1083-1098.

Hillebrand H, Dürselen CD, Kirschtel D, Pollingher U, and Zohary T. 1999. Biovolume calculation for pelagic and benthic microalgae. J. Phycol. 35: 403-424.

Hollander DJ, and McKenzie JA. 1991. $\mathrm{CO}_{2}$ control and carbon-isotope fractionation during aqueous photosynthesis: a paleo-pCO ${ }_{2}$ barometer. Geology 138: 929-932.

Jones RI, Grey J, Quarmby C, and Sleep D. 1998. An assessment using stable isotopes of the importance of allochthonous organic carbon sources to the pelagic food web in Loch Ness. Proc. Royal Soc. Lond. B. 265: 105-111.

Kamenir Y, and Morabito G. 2009. Lago Maggiore oligotrophication as seen from the long-term evolution of its phytoplankton taxonomic size structure. J. Limnol. 68: 146-161.

Kruk C, Huszar VLM, Peeters E, Bonilla S, Costa L, Lurling M, Reynolds CS, and Scheffer M. 2010. A morphological classification capturing functional variation in phytoplankton. Freshwater Biol. 55: 614-627.

Leggett MF, Johannsson O, Hesslein R, Dixon DG, Taylor WD, and Servos MR 2000. Influence of inorganic nitrogen cycling on the $\delta^{15} \mathrm{~N}$ of Lake Ontario biota. Can. J. Fish. Aquat. Sci. 57: 1489-1496

Leggett MF, Servos MR, Hesslein R, Johannsson O, Millard ES, and Dixon DG. 1999. Biogeochemical influences on the carbon isotope signatures of Lake Ontario biota. Can. J. Fish. Aquat. Sci. 56: 2211-2218.

Lehman JT, Abella S, Litt AH, and Edmondson WT. 2004. Fingerprints of biocomplexity: Taxon-specific growth of phytoplankton in relation to environmental factors. Limnol. Oceanogr. 49: 1446-1456.

Litchman E, de Tezanos Pinto P, Klausmeier CA, Mridul KT, and Yoshiyama K. 2010. Linking traits to species diversity and community structure in phytoplankton. Hydrobiologia 653: $15-28$.

Litchman E, and Klausmeier CA. 2008. Trait-based community ecology of phytoplankton. Ann. Rev. Ecol. Evol. Syst. 39: 615-639.

Litchman E, Klausmeier CA, Schofield OM, and Falkowski PG. 2007. The role of functional traits and tradeoffs in structuring phytoplankton communities: scaling from cellular to ecosystem level. Ecol. Lett. 10: 1170-1181.

Lorenzen CJ. 1967. Determination of chlorophyll and pheopigments: spectrophotometric equations. Limnol. Oceanogr. 12: 343-346.

Lund JW, Kipling C, and Le Cren ED. 1958. The inverted microscope method of estimating algal numbers and the statistical basis of estimation by counting. Hydrobiologia 11: 143-170.

Manca M, Visconti A, Fadda A, Caroni R, Cerutti I, and Volta P. 2009. Indagini sullo zooplancton e sulla rete trofica pelagica attraverso analisi d'isotopi stabili di carbonio e azoto. In: C.N.R.-I.S.E. (Ed.), Ricerche sull'evoluzione del Lago Maggiore. Aspetti limnologici. Programma quinquennale 20082012. Campagna 2008. Commissione Internazionale per la protezione delle acque italo-svizzere: 35-52.

Margalef R. 1978. Life forms of phytoplankton as survival alternatives in an unstable environment. Oceanol. Acta 1: 493509.

McCune B, and Mefford MJ. 2004. HyperNiche. Nonparametric Multiplicative Habitat Modeling MjM Software, Oregon.

McCune B, and Mefford MJ. 2006. PC-ORD. Multivariate Analysis of Ecological Data. MjM Software, Oregon.

Michener RH, and Schell DM. 1994. Stable isotope ratios as tracers in marine aquatic food webs. In: K. Lajtha and R.H. Michener (Eds), Stable Isotopes in Ecology and Environmental Science. Blackwell Scientific, London: 138-157.

Mook WG, Bommerson JC, and Stavermen WH. 1974. Carbon isotopes fractionation between dissolved bicarbonate and gaseous carbon dioxide. Earth Planet. Sci. Lett. 22: 169176.

Morabito G, Ruggiu D, and Panzani P. 2002. Recent dynamics (1995-1999) of the phytoplankton assemblages in Lago Maggiore as a basic tool for defining association patterns in the Italian deep lakes. J. Limnol. 61(1): 129-145.

Morabito G, Sili C, Panzani P, and Oggioni A. 2009. Dinamica stagionale e distribuzione orizzontale di fitoplancton, carbonio organico e batterio plancton. Struttura dei popolamenti fitoplanctonici. In: C.N.R.-I.S.E. (Ed.), Ricerche sull'evoluzione del Lago Maggiore. Aspetti limnologici. Programma quinquennale 2008-2012. Commissione Internazionale per la protezione delle acque italo-svizzere: $53-$ 66.

Parker PL. 1964. The biogeochemistry of the stable isotopes of 
carbon in a marine bay. Geochim. Cosmochim. Acta 28: 1155-1164.

Perga ME, and Gerdeaux D. 2006. Seasonal variability in the $\delta^{13} \mathrm{C}$ and $\delta^{15} \mathrm{~N}$ values of the zooplankton taxa in two alpine lakes. Acta Oecol. 30: 69-77.

Peterson BJ, and Fry B. 1987. Stable isotopes in ecosystem studies. Ann. Rev. Ecol. Syst. 18: 293-320.

Phillips G, Morabito G, Carvalho L, Solheim AL, Skjelbred B, Moe J, Andersen T, Mischke U, de Hoyos C, and Borics G. 2011. Deliverable D3.1-1: Report on lake phytoplankton composition metrics, including a common metric approach for use in intercalibration by all GIGs. www.wiser.eu

Popp BN, Laws EA, Bidigare RR, Dore JE, Hanson KL, and Wakeham SG. 1998. Effect of phytoplankton cell geometry on carbon isotopic fractionation. Geochim. Cosmochim. Acta 62: 66-77.

Post DM. 2002. Using stable isotopes to estimate trophic position: models, methods, and assumptions. Ecology 83: 703718.

Rau GH, Riebesell U, and Wolf-Cladrow D. 1996. A model of photosynthetic fractionation by marine phytoplankton based on diffusive molecular $\mathrm{CO}_{2}$ uptake. Mar. Ecol. Prog. Ser. 133: 275-285.

Rau GH, Takahashi T, and des Marais DJ. 1989. Latitudinal variations in plankton $13 \mathrm{C}$ : implications for $\mathrm{CO}_{2}$ and productivity in past oceans. Nature 341: 516-518.

Rau GH, Takahashi T, des Marais DJ, Repeta DJ, and Martin JH. 1992. The relationship between ${ }^{13} \mathrm{C}$ of organic matter and $\left[\mathrm{CO}_{2}(\mathrm{aq})\right]$ in ocean surface water: data from a JGOFS site in the northeast Atlantic Ocean and a model. Geochim. Cosmochim. Acta 56: 1413-1419.

Reynolds CS. 1984. The ecology of freshwater phytoplankton. Cambridge University Press, Cambridge.

Reynolds CS, Huszar V, Kruk C, Naselli-Flores L, and Melo S. 2002. Towards a functional classification of the freshwater phytoplankton. J. Plankton Res. 24: 417-428.

Reynolds CS, and Irish AE. 1997. Modelling phytoplankton dynamics in lakes and reservoirs: the problem of in situ growth rates. Hydrobiologia 349: 5-17.

Rott E. 1981. Some results from phytoplankton counting intercalibrations. Schweizerische Zeitschrift für Hydrologie, 43: 34-63.

Salmaso N. 2000. Factors affecting the seasonality and distribution of cyanobacteria and chlorophytes: a case study from the large lakes south of the Alps, with special reference to Lake Garda. Hydrobiologia 337: 49-68.

Salmaso N, and Padisak J. 2007. Morpho-functional groups and phytoplankton development in two deep lakes (Lake Garda, Italy and Lake Stechlin, Germany). Hydrobiologia 578: 97112.

Takahashi K, Yoshioka T, Wada E, and Sakamoto M. 1990. Temporal variations in carbon isotope ratio of phytoplankton in a eutrophic lake. J. Plankton Res. 12: 799-808.

Utermöhl H. 1958. Zur vervollkommnung der quantitativen phytoplanktonmetodik. Verh. Internat. Verein. Theor. Angew. Limnol. 9: 1-38.

Vander Zanden MJ, and Rasmussen JB. 1999. Primary consumer $13 \mathrm{C}$ and $15 \mathrm{~N}$ and the trophic position of aquatic consumers. Ecology 80: 1395-1404.

Visconti A, and Manca M. 2011. Seasonal changes in the $\delta^{13} \mathrm{C}$ and $\delta 15 \mathrm{~N}$ signatures of the Lago Maggiore pelagic food web. J. Limnol. 70: 263-271.

Vuorio K, Meili M, and Sarvala J. 2006. Taxon-specific variation in the stable isotopic signatures $\left({ }^{13} \mathrm{C}\right.$ and $\left.{ }^{15} \mathrm{~N}\right)$ of lake phytoplankton. Freshwater Biol. 51: 807-822.

Zohary T, Erez J, Gophen M, Berman-Frank I, and Stiller M. 1994. Seasonality of stable carbon isotopes within the pelagic food web of Lake Kinneret. Limnol. Oceanogr. 39: 1030-1104. 